\title{
Rejoinder: on terminology, functionalism, (historical) institutionalism and liberalization
}

\author{
Wolfgang Streeck \\ Max Planck Institute for the Study of Societies, Paulstr. 3, 50676 Köln, Germany \\ Correspondence: E-mail: ws@mpifg.de
}

Authors receiving such impressive comments on their work as we did must be grateful even if some of the comments are critical. Since criticism is essential to scholarly progress, they might even be tempted to respond that critical debate was all they ever wanted to achieve. But given the significance of the themes raised by Herrigel, O'Sullivan and Pempel, this would be all too complacent. Respecting inevitable limitations of space, I want to focus on three issues that to me are the most important. First, I will try to defend our choice of terminology, pointing out what its purpose was and what it was not. Second, I will address the relationship between economical functionalism and historical institutionalism, hoping to be able to bring out how one might try to reconcile the two. And third, I will briefly register agreement with Pempel that our books are still far from offering a convincing political account of the complex process of economic liberalization currently under way in the two countries we have studied.

\section{The conceptual framework}

In this respect we were not nearly as ambitious as some of our readers seem to believe. In fact, the decisions we made here were of a rather ad hoc kind, driven more or less pragmatically by the empirical puzzle that we were trying to address. (Is this, perhaps, how conceptual decisions should generally be made?) That puzzle is conveniently summarized in three observations that were at the time shared by many others: (a) that the economic orders of Germany and Japan were considerably less market-driven than those of other countries-like the US and, to some extent at least (e.g. see Dore, 1973, 1987), the United Kingdom; (b) that, astonishingly and indeed provocatively to many, they had nevertheless for some time done significantly better than more market-driven national 
economies; and (c) that they had now both moved into stagnation and crisis, as a result of which they had come under pressure to reorganize themselves in a more market-driven fashion, ironically in the image of the very countries that they had outperformed for almost two decades (for a somewhat different phrasing of the same problem see Streeck, 2001, p. 1, 3; Streeck and Yamamura, 2003, pp. 1-2).

To formulate our puzzle we needed proper concepts. Capitalism, which was what we were dealing with, we conceived, not very originally, to be an economic system based on private property and the allocation of values through selfregulating markets. Of course there exist in capitalism also states and public property, and some exchanges take place at administered prices instead of by free allocation - and in some countries, like Germany and Japan, more than in others. The greater the role of private property and free markets, the more capitalist a capitalist system could be said to be. But one could also say the more liberal, given that private property and free exchange are the historical essence of liberalism. So we decided to distinguish between different versions of capitalism in terms of their degree of liberalism, with Germany and Japan coming out historically less liberal than the US or the UK. To simplify further, or so we hoped, we polarized our property space and moved from the gradual distinction between more and less liberal to the categorical distinction between liberal and non-liberal, assuming that everybody would understand what this was intended to mean and what was not.

With hindsight the flaws of this construction are obvious, and not surprisingly they become all the more visible if one attempts to make the construction bear a heavier burden than it was proposed for. It is quite true, as Mary O'Sullivan reminds us, that we did not inquire into the details of American and British capitalism and the many differences that no doubt exist between them. It is also true that we did not discuss the unquestioned importance of non-liberal elements in American capitalism, such as the NIH research budget or the militaryindustrial complex. Similarly, we are clearly guilty sometimes of stylizing the facts especially of US capitalism in terms of what we, somewhat ironically, call the 'standard capitalism' of 'standard economics' (Streeck, 2001, p. 5). Had our books been intended to provide an empirical comparison between Germany and Japan on the one hand and, say, the US and the UK on the other, this would be unforgivable. But this was not our intention. All we needed, or so we thought, was to provide some sort of background awareness, based on what we felt was widespread consensus among political economists, that there were capitalisms out there that were more capitalist, or 'liberal', than the 'Japanese model' or the 'German model' of the 1970s and 1980s; and that these had gained ascendancy while the 'non-liberal', less capitalist systems of Germany and Japan had moved from dominance to decline (cf. Streeck, 2001, p. 5). 
In other words, our typology, or more modestly, our simplified categorical distinction was devised only for the purpose at hand. It was certainly not devised as a theory to compete, for example, with the theory we believe is behind the apparently related distinction between liberal and coordinated market economies (Hall and Soskice, 2001). ${ }^{1}$ That theory, as we read it, implies refutable hypotheses to the effect that the world of possible capitalisms divides into two and only two classes, and that because of internal and external pressures for functional complementarity between its elements, every capitalist system must sooner or later locate itself into one of the two camps. Nothing like this is implied in our two books, or at least no such implication is intended.

In fact, if one were to draw out the assumptions that more or less visibly underlie our concepts, our strong emphasis on the differences between the two countries in our non-liberal, or less liberal, category (see Streeck, 2001, pp. 3-4, 25) would stand out even more than it apparently does now. Obviously we do regard it as an important similarity between Germany and Japan that both are, and have long been, less 'liberal', in our terms, than imagined or prescribed by standard capitalist economics. However, nowhere do we suggest that this common characteristic should be of such pervasive causal power as to determine all other characteristics of the two economic and political systems. Certainly, our account of the enormous differences of the two countries' reactions to their current calamities (Streeck and Yamamura, 2003, pp. 5-17) implies that simply being 'non-liberal' is not enough to produce identical or similar responses to pressures for liberalization. When we repeatedly emphasize the differences, not just between Germany and Japan, but within any conceivable category of 'capitalisms', we implicitly but unmistakably subscribe to Max Weber's view of social formations as 'historical individuals' (Weber, 1904). While shaped by causal mechanisms that can be generalized and 'ideal-typically' modelled, historical individuals are unique; they must be understood and explained on their own terms since the forces that form them are both at crossroads with each other and operate in historically contingent combinations and circumstances. ${ }^{2}$

An important implication of this approach is, incidentally, that the national 'models' of (non-liberal) capitalism that we are dealing with resist reification as they are continually in flux. Historical individuals can only be conceived as dynamic. Rather than systems in equilibrium, they are the temporary and

\footnotetext{
${ }^{1}$ For a somewhat less pragmatic discussion of the concept of non-liberal capitalism, which draws heavily on the notion of social embeddedness of economic transactions while, again, making no claim whatsoever to originality, see Streeck (2001, pp. 2-3, 7) and Streeck and Yamamura (2003, pp. 2-3). We also occasionally speak of 'nationally embedded' or 'nationally organized' capitalism, which indicates how little attached we are to our main concepts.

${ }^{2}$ Every country's Weg, we said in an earlier draft, is a Sonderweg. Unfortunately, this line was deleted by a copy editor under orders, presumably, to minimize the use of outdated languages.
} 
idiosyncratic products of fleeting configurations of competing causal forces entering an unending permutation of local compromises with one another. German and Japanese capitalism were never 'done'-and this, not the limitations of our empirical research, is the reason for our difficulties, as pointed out by O'Sullivan, in dating them. As especially our second volume shows, what was called the 'German model' 20 years ago was a post-war synthesis that was already coming apart at the time it was discovered, and much the same can be said of the 'Japanese model' (see Streeck, 2001, p. 36). Moreover, both 'systems' differed greatly from their respective predecessors in the 1930s, which were again different from, say, what existed in the 1890s. Equally importantly, there still seem to have been at each point in time differences between the two countries on the one hand and the Anglo-American world on the other that by and large seemed to fit the crude distinction between liberal and non-liberal that we adopted to organize our material. Moreover, although it appears to have been generally impossible to foresee in the two countries' histories how their national 'models' of capitalism would develop in the future (Streeck, 2001, p. 30), with hindsight one finds non-trivial elements of historical identity in spite of, and inside, a steady stream of continuous and often disruptive change. These elements we have tentatively characterized as the corporatist and the ie traditions, respectively (Streeck, 2001, p. 25), which over a long time seem to have provided the two societies of our study with different and specific blueprints for the reorganization of political-economic institutions in crisis. ${ }^{3}$ The presence of such continuities within continuous change is one of the reasons for our expectation, with all due caution, that Germany and Japan will come out of the present process of liberalization remaining distinct from other countries, although this may be in ways that are impossible to know beforehand.

\section{Functionalism or historical institutionalism?}

In her penetrating comment Mary O'Sullivan notes 'a strong and recurrent tension' in the two books 'between two rather different types of institutional analysis', which she calls 'functionalism' and 'historical institutionalism'. The functionalist part of the analysis she characterizes as claiming 'that particular systems of capitalism provide institutional support for different types of competitive strategies and economic performance' while the historicalinstitutionalist approach 'emphasizes the constant, unintended, contingent and

\footnotetext{
${ }^{3}$ Recently Arndt Sorge has, in a beautiful book on the societal logic of 'globalization' drawing on the longue durée history of Germany, introduced the concept of a national 'meta-tradition' to account for similarities over long periods of time in the responses of societies to the continuous expansion of their social and economic horizons (Sorge, 2005).
} 
path-dependent characteristics of the historical process of institutional change'. O'Sullivan continues:

From this (latter) perspective, institutions come together in some kind of logical way through fortune rather than by design. As such, the historical institutionalist strand in the books describes the process of institutional change as much less orderly, more chaotic, than most functionalists would assume it to be, at least if they were to seek to explain the origins of the institutions whose functional characteristics concern them.

Gary Herrigel, in his comment, makes a similar point, although he tends to identify institutionalism in general with what to O'Sullivan is only the functionalist subtype of institutionalism. The two books, Herrigel says, 'view the institutional systems in Japan and Germany as highly coherent, unitary systems of interconnected and complementary institutional realms of governance'. The 'models' - of non-liberal capitalism-that such a perspective enables one to construct may be 'ideologically useful'. Nevertheless, their coherence

is ultimately an abstraction that blends out a great deal of anomalous relationships, habits, dispositions and institutional practices in both societies ... It also creates the impression that such institutional systems exist 'on the ground' as clear bright line rules that guide behaviour... The bedrock institutionalist commitments of the authors and editors stand here unadorned. Their coherent models of complementary institutions rely on the traditional institutionalist idea that institutions impose constraints and enforceable obligations on actors.

But this, according to Herrigel, is fundamentally misleading:

The actual systems in Germany and Japan ... are much more incoherent, non-unitary and provisional than they are portrayed in either of the volumes. Rather, they are composed of a patchwork of different institutional solutions to a wide array of political economic problems. The range of solutions work alongside on another not only (or not even) in complementary ways, but also in relations of nonparalysing juxtaposition. Indeed, it is difficult, on the ground, to identify a coherent, stable system of constraining rules in Japan and Germany (or anywhere else for that matter).

I have quoted Herrigel so extensively for two reasons: to show how close his self-perceived anti-institutionalism is to O'Sullivan's historical institutionalism, and because I feel so sympathetic with the way he describes the world. 
O'Sullivan's advice at the end of her comment 'to play down the functionalist discussion and play up the historical institutionalism ... relying heavily on concepts such as path dependence, hybridization and bounded innovation' I take to be pointing in the same direction as Gary Herrigel. As far as I am concerned, this is a direction in which all that the two commentators can do is crash into open doors-what we call in German 'offene Türen einrennen'. My only reservation with respect to Herrigel is that, in order to get rid of functionalist institutionalism, he seems to favour discarding institutionalism as such. I also have a problem with O'Sullivan's endorsement of historical as opposed to functionalist institutionalism, which may however be less important than it appears at first glance.

I begin with O'Sullivan. My question to her is, in brief, how and to what extent should functional or efficiency constraints be treated as causal factors shaping institutions and their (national) configurations. On the basis of what I read, I would expect her answer to be miles away from the economistic efficiency theories of social institutions that are so popular in today's rational choice theorizing. Needless to say I would endorse this very strongly. But in doing so I want to avoid encouraging her altogether to abandon concepts like competitive advantage, functional coherence and complementarity, national economic competitiveness, etc. that have inspired such rich and stimulating literature. ${ }^{4}$ To me this would be like throwing away the theoretical baby with the economistic bath water. Instead we better combined our efforts to solve the tricky problem of how to integrate economic concerns and pressures for economizing into a non-functionalistic, non-economistic, i.e. historical and sociological theory of institution-building and institutional change-basically what I understand O'Sullivan calls historical institutionalism. To me this is the problem par excellence of any institutionalist political economy, which is another way of saying of any political economy with the ambition of dealing with the real world.

How to go about this? At the least, I believe, theories of economic institutions must dissociate themselves from the series of assumptions that more or less implicitly underlie most variants of what may be called economistic functionalism. I limit myself to two of these. ${ }^{5}$ The first is that economic performance and functional complementarity of institutions result from purposive design, either from the top down by an interventionist state or from the bottom up by business firms concerned about their competitiveness. Institutionalist theory, precisely

\footnotetext{
${ }^{4}$ In addition to Hall and Soskice (2001), see Crouch and Streeck (1997), Aoki (2001) and Amable (2003), among others.

${ }^{5}$ For more on this see Streeck (2004a) and my contribution to the recent debate in this journal on the concept of complementarity (Streeck, 2005).
} 
when it is dealing with economic institutions, must fully take on board the realities of limited foresight and limited control, multiple and conflicting objectives, ambiguous external constraints and opportunities, and an unpredictably changing task environment. Economically functioning institutions are constructed, if at all, under and out of such conditions. Both process and result of institution-building reflect these conditions and cannot be accounted for without extensive reference to them.

The other assumption that I believe one might want to avoid is that politicaleconomic institutions, or institutional configurations, are selected by a perfect market which eliminates the inefficient and leaves the efficient. There are many reasons why this would seem highly unrealistic. Institutions that are less efficient than desirable do not normally disappear to be replaced wholesale by customdesigned new institutions. As a rule institutional settings change, not through institutional breakdown, but through institutional change. Change, however, proceeds only slowly as institutions are by their nature inert. Moreover, institutional environments are far more volatile and ambiguous than institutions can possibly be flexible, which makes institutional change in pursuit of economic efficiency a highly risky pursuit of a rapidly moving target. Among other things, this makes it advisable to preserve as many alternative options as possible. Also, where real-world institutions compete with each other for comparative advantage, they measure themselves, not against absolute standards of optimal performance, but against the actual performance of similar historical, compromised and multi-functional entities like themselves. This leaves those who control them a broad band of strategic choice between equally satisfactory (or unsatisfactory) 'functional equivalents'. All this goes to suggest that the difference between the mechanisms that drive institutional change and the market is more than one of degree, rendering a market model of institutional change not just unrealistic but fundamentally useless.

In what sense, then, may institutions be regarded as economically functional in historical institutionalism, and what is it that makes them so? In our two books we have repeatedly pointed to the importance of chance-of good luck as opposed to merit or virtue-as well as to the historically contingent character of the challenges faced by institutional systems. Generally it would seem that in reality, economizing comes in mostly ex post as actors seek to reconcile in a creative, 'Schumpeterian' way the institutionalized 'givens' of their social world with economic interests and objectives, pragmatically trying to make the best out of necessity or historical inevitability. I have outlined this perspective in my paper on 'Beneficial Constraints' (Streeck, 1997) and in a recent debate on that paper with Wright and Tsakalatos in this journal (Streeck, 2004b). Ex-post economizing by 'making-do' - fitting together from below what nobody was able to design coherently from above-may be precisely what happens in the interstices of 
functionally interdependent institutions built with distributed power and in pursuit of particularistic sectoral interests.

Concerning Herrigel, my question to him is whether institutions, in the way he uses the term, are at all constraining — which in Durkheimian language would amount to asking whether his institutions actually are ones. Herrigel writes:

Actors allow themselves to be constrained by rules when they believe those rules solve problems. When they do not, creative actors coping with uncertainty and guided by dispositions that are not reducible to specific institutional arrangements either modify the rules or agree simply to ignore them in order to construct new arrangements that address more directly jointly identified problems.

To me this is going a step too far. Abandoning institutionalist functionalism is one thing, abandoning institutionalism another. I strongly support Herrigel's effort to 'soften up' institutional analysis and avoid the determinism that often undermines its credibility, for example by making it impossible to conceive of continuous institutional change in the absence of exogenous disruption. But this cannot mean that social action must be conceptualized as completely voluntaristic. Together with Kathleen Thelen I have recently suggested a model of institutional change that emphasizes continuous interaction between rule-makers and rule-takers puzzling and arguing over the meaning of institutionalized rules in the diverse and changing conditions in which they are supposed to be applied (Streeck and Thelen, 2005). I believe that this model does allow, as Herrigel puts it in the above quote, for actors to 'modify the rules or agree simply to ignore them'. At the same time, it does not allow to forget that institutionalized rules are protected by social sanctions that may be effectively applied in their defence. While sanctions may fail, they may still be strong enough to prevent local actors from, again in Herrigel's words, 'construct[ing] new arrangements that address more directly jointly identified problems'. Could it be that foreclosure of pragmatically attractive alternatives by institutionalized sanctions is more characteristic of the 'non-liberal' capitalisms of Europe and Japan than of the US? On the whole I doubt it.

\section{The politics of liberalization in Germany and Japan}

At the end of his comment T. J. Pempel expresses the view that our two books pay too little attention to the political factors, and actors, who have in the past produced the similarities and differences between Germany and Japan and are today governing the responses of the two countries to the new challenges of 'globalization'. In particular, Pempel mentions the role of organized labour, the political 
forces behind the liberalizing 'reforms' of today, and the changed role and interests of the US in the global system. While I do not fully subscribe to his reading, I admit that we did and still do lack an adequate understanding of the present politics of liberalization in non-liberal capitalism. Pempel himself points to the contradiction that in social-democratic Germany it was the labour market that had to bear the brunt of the crisis of the 1990s, whereas in Japan's 'corporatism without labour' (Pempel and Tsunikawa, 1979) the crisis first hit the capital markets. Presumably this was related to the fact that Japan still is a sovereign nation with its own monetary policy, unlike Germany which was prevented by European Monetary Union from using (or, depending on one's perspective, abusing) fiscal and monetary policies to protect the employment of its industrial working class. It also had to do with the fact that in Germany there was a public welfare state ready and able_-although, as it turned out, within strict limits—-to absorb the labour surplus generated by privatization and 'lean production', while in Japan the stability of the national social compact depended on stable employment in that country's large private firms.

Moreover, Pempel correctly observes that already in the 1970s the United States was no longer willing to underwrite the post-war illusion of national economic sovereignty and social-political autonomy inside the 'Free World', as instituted by the global regime of 'embedded liberalism'. In the late 1990s the US had begun aggressively to push for a new wave of international liberalization, and especially for the opening up of the economies of its two main rivals, Germany and Japan, to international markets and American firms. National governments also contributed, in Germany more than in Japan, by promoting internationalization in order to weaken domestic organized interests that had grown too powerful for national economies to keep manageable. 'Globalization', which is often simplistically described as the inevitable effect of improved means of cross-border communication and the subsequent increase in cross-border ties, was to an important extent a defensive reaction of governments who found increasingly impossible the task of running the mixed economies they had inherited from the post-war era. Capital, tired of the costly national politics of entitlement that had emerged out of post-war democratization, supported this reaction and often did its best to make it inevitable. 'Globalization', it seems, was and is two things at the same time: a political contraption to restore sound money, free markets and managerial prerogative, and also a structural force more or less successfully constraining politics to move upwards to a new level above the nation-state, with complex effects on the way in which the economy is embedded in stabilizing social institutions or, for that matter, disembedded. Have nationstates lost control through global liberalization, or have they promoted global liberalization to regain control? Is global governance tantamount to the political and legal civilization of the nation-state from without, or to the de-civilization of 
the economy from within? As so often, the only thing we seem to know for certain is 'more research is needed'.

\section{References}

Amable, B. (2003) The Diversity of Modern Capitalism, Oxford, Oxford University Press.

Aoki, M. (2001) Toward a Comparative Institutional Analysis, Cambridge and London, The MIT Press.

Crouch, C. and Streeck, W. (eds) (1997) The Political Economy of Modern Capitalism: Mapping Convergence and Diversity, London, Sage Publishers.

Dore, R. (1973) British Factory, Japanese Factory: The Origins of national Diversity in Industrial Relations, Berkeley, CA, University of California Press.

Dore, R. (1987) Taking Japan Seriously: A Confucian Perspective on Leading Economic Issues, Stanford, Stanford University Press.

Hall, P. and Soskice, D. (eds) (2001) Varieties of Capitalism: The Institutional Foundations of Comparative Advantage, Oxford and New York, Oxford University Press.

Pempel, T. J. and Tsunekawa, K. (1979) 'Corporatism without Labor? The Japanese Anomaly'. In Schmitter, P. C. and Lehmbruch, G. (eds) Trends Toward Corporatist Intermediation, London, Sage Publishers.

Sorge, A. (2005) The Global and the Local: Understanding the Dialectics of Business Systems, Oxford, Oxford University press.

Streeck, W. (1997) 'Beneficial Constraints: On the Economic Limits of Rational Voluntarism'. In Hollingsworth, J. R. and Boyer, R. (eds) Contemporary Capitalism: The Embeddedness of Institutions, Cambridge, Cambridge University Press, pp. 197-219.

Streeck, W. (2001) 'Introduction: Explorations into the Origins of Nonliberal Capitalism in Germany and Japan'. In Streeck, W. and Yamamura, K. (eds) The Origins of Nonliberal Capitalism: Germany and Japan in Comparison, Ithaca and London, Cornell University Press, pp. 1-38.

Streeck, W. (2004a) 'Taking Uncertainty Seriously: Complementarity as a Moving Target', Workshop Proceedings of the Österreichische Nationalbank, 1(1), 101-15.

Streeck, W. (2004b) 'Educating Capitalists: A Rejoinder to Wright and Tsakalatos', SocioEconomic Review, 2(3), 425-83.

Streeck, W. (2005) 'Requirements for a Useful Concept of Complementarity', SocioEconomic Review, 3(3), 366-68.

Streeck, W. and Thelen, K. (2005) 'Introduction: Institutional Change in Advanced Political Economies'. In Streeck, W. and Thelen, K. (eds) Beyond Continuity: Institutional Change in Advanced Political Economies, Oxford, Oxford University Press, pp. 2-39. 
Streeck, W. and Yamamura, K. (2003) 'Introduction: Convergence or Diversity? Stability and Change in German and Japanese Capitalism'. In Yamamura, K. and Streeck, W. (eds) The End of Diversity? Prospects for German and Japanese Capitalism, Ithaca and New York, Cornell University Press, pp. 1-50.

Weber, M. (1904) 'Die “Objektivität” sozialwissenschaftlicher und sozialpolitischer Erkenntnis', Archiv für Sozialwissenschaft und Sozialpolitik, 19(1), 503-74. 